\title{
INSIGHT:
}

\section{THE INTERPRETATION OF ISLAM WITHIN THE LEGAL FRAMEWORK OF THE INDIGENOUS MALAYA}

\author{
Wan Ahmad Fauzi bin Wan Husain ${ }^{1,2}$ \\ ${ }^{1}$ Faculty of Industrial Management, Universiti Malaysia Pahang \\ 2Director, The Institute of Civilization and Strategic Research
}

\begin{abstract}
This article promotes Islam's interpretation within the legal framework of the indigenous Malayan based on its principle of sovereignty. At present, Islam is popularly defined by the Court's decision in Che Omar Che Soh vs Public Prosecutor, where the sovereignty of the Malay Rulers was made as a parameter in interpreting Islam within the context of Article 3 of the Federal Constitution. The said decision confines Islam only in the context of personal laws due to the Pangkor Treaty, 1874. This is a qualitative study applying the legal history design. The findings showed that the indigenous sovereignty sourced from the Islamic teachings had not been affected despite the introduction of doctrine of advice and various British policies throughout their intervention in Malaya. In fact, many agreements made between the Malay Rulers and the British retained the indigenous sovereignty as those agreements were subjected to the old Malayan Constitution, the principle of Islam as the law of the land as well as the contemporary local thinking. The above three local circumstances explained the principle of sovereignty, thus the position of Islam in the indigenous Malaya's legal framework. This article concludes that the accurate interpretation of Islam should be based on the al-Qur'an and al-Sunnah because the Malay Rulers have retained their position as a caliph even after the British intervened in their internal state affairs.
\end{abstract}

\author{
ARTICLE HISTORY \\ Received: $20-11-2020$ \\ Revised: $13-12-2020$ \\ Accepted: 8-1-2021

\section{KEYWORDS} \\ Old Malayan Constitution, \\ sovereignty, \\ law of the land, \\ Article 3, \\ The World Class Good \\ Governance Ethics
}

\section{INTRODUCTION}

The interpretation of Islam by Salleh Abas, LP in the case of Che Omar Che Soh vs Public Persecutor that reads, "Islamic law was rendered isolated in a narrow confinement of the law of marriage, divorce and inheritance only" was based on a misdirected observation. The misdirected observation taken from the phrase, "In our view, it is in this sense of dichotomy that the framers of the Constitution understood the meaning of the word 'Islam' in the context of Article 3" was reversed by Ahmad Fairuz, CJ in the case of Lina Joy vs the Federal Islamic Religious Council \& Ors when the majority decided on the following:

Islam is not just a set of dogmas and rituals, but it is also a complete way of life embracing all fields of human activities, private or public, legal laws, political, economic, social, cultural, moral or judicial. And if examined thoroughly, it was obvious Articles 11 (1), 74 (2) and item 1 in list 2 in Schedule 9 PP that Islam encompasses, among others, the Islamic laws.

Even though the interpretation of Islam by Salleh Abas LP in the case of Che Omar Che Soh vs Public Prosecutor was reversed, it is critical to revisit his ground of Judgment since his lordship had interestingly argued the position of the Malay Rulers' sovereignty before arriving at the interpretation of Islam in the context of the Federal Constitution. Another critical aspect of the said decision is that Islam's interpretation would determine the validity of laws passed by the Parliament. In the above case, there were two interpretations of Islam being considered, namely:

\footnotetext{
The first point to consider here is the meaning which could be given to the expression 'Islam' or 'Islamic religion' in Article 3 of the Constitution. If Islam's religion in the context means only such acts as related to rituals and ceremonies, the argument has no basis whatsoever. On the other hand, if the religion of Islam or Islam itself is an all-embracing concept, as is typically understood, which consists not only the ritualistic aspects but also a comprehensive system of life, including its jurisprudence and moral standard, then the submission has a significant implication in that every law has to be tested accordingly to this yardstick.
}

There can be no doubt that Islam is not just about a mere collection of dogmas and rituals but a whole way of life covering all fields of human activities, whether they be private or public, legal, political, economic, social, and cultural, moral or judicial. This way of ordering the life with all the precepts and moral standards is based on divine guidance through His prophets, and the last of such guidance is the al Quran, and the last messenger is Mohammad SAW whose conduct and utterance are revered (see S Abul A'ala Maududi, The Islamic Law and Constitution, March 1980, seven ${ }^{\text {th }}$. Edition). 


\section{Objective}

Hence, this article's main objective is to explain the interpretation of Islam within the legal framework of the indigenous Malaya. Such interpretation is critical to argue the observation made by Salleh Abas, LP in the case of Che Omar Che Soh vs Public Prosecutor while analysing the effects of the Pangkor Treaty, 1874 and Article 162 of the Federal Constitution on the existing law which includes in its definition the states constitution before the Independence Day (Hari Merdeka). Subsequently, such interpretation denotes Islam's true definition in Article 3 of the Federal Constitution, thus clarifying the principle of the highest governance in the present Malaysian legal framework.

\section{LITERATURE REVIEW}

The Supreme Court's decision in Che Omar Che Soh vs Public Prosecutor became the subject of review and this article's argument centred on the critical issues and events discussed by Salleh Abas, LP. More information can be found in the sections after methodology.

\section{METHODOLOGY}

This article uses local jurisprudence (Jurisprudens Watan) that promotes legal history as a research design to define Islam's interpretation. Relevant data and evidence were collected from the Old Malayan Constitution and the reliable customary and legal sources in Malaya. The primary issues are critically analysed using legal doctrines based on a qualitative study. This study focuses on the Malay Rulers' position viewed from the three legal perspectives; they are the Old Malayan Constitution, the law of the land and contemporary local thinking. These three sources are most valid, relevant and credible evidence to determine the principle of sovereignty and the interpretation of Islam within the framework of the indigenous Malaya.

\section{THE INDIGENOUS SOVEREIGNTY}

Generally, sovereignty refers to the concept of supreme authority that determines the legal principles in a political entity and legislation, i.e. the concept of the supreme power which could not be stripped by any internal or external power; to carry out political decisions, to enact and enforce laws based on the characteristics of its sovereignty within its territorial jurisdiction (Wan Ahmad Fauzi: 2017). Sovereignty by the Western and Islamic thoughts was a concept that had implications on the political system and legal principles of a government or state (Curzon, Dictionary of Law: 2007; Wan Ahmad Fauzi: 2017).

The distinction of sovereignty between Western thought and Islam is from the source of sovereignty. The Western thinking placed sovereignty on the people or certain entities such as parliament that required the sovereign power to be absolute, free and independent when making decisions. On the other hand, Islam places absolute sovereignty on Allah SWT, while the government or rulers is merely a trustee, far from absolute. From the Islamic perspective, free and independent means the freedom to execute Allah SWT's command and the teachings of Prophet Muhammad (PBUH).

Hence, it must be understood that the sovereign government maintains its independence and is not colonised. As such, the sovereign ruler and his government are not under any form of adverse subordination or control. The colonisation would only occur if a government's sovereignty, including all its characteristics, were relinquished either due to war or was replaced by a different entity. However, according to the Islamic perspective, Allah SWT's sovereignty could only be suspended when people are ignoring religious sanctions. This is because the responsibility to execute the command of Allah SWT is infinite and could not be eliminated by anyone. If it was suspended, then it becomes the obligation of the Muslims to restore it.

As further explained by Wan Ahmad Fauzi (2018), the Malayan sovereignty referred to the framework of Islamic sovereignty originating from the establishment of the Malayan Malay Sultanate that occurred earlier or later therefrom. Thus, the Malayan indigenous sovereignty is a supreme authority concept derived from the Islamic Shari'a (Islamic laws) based on faith that asserted the highest legislation is Allah SWT's absolute right as described in the al-Qur'an and alSunnah. Based on that conceptual framework, then:

1. Human leadership, including the Malay Rulers, is positioned as Khalifah (Caliph), or the sovereign trustee to the almighty Allah SWT.

2. The sovereignty principle outlines the political system's general policies and the legal principles (the teachings of Islam) that are mandatory guidance to man throughout all time and places.

3. The man could legislate laws and policies, but such legal orders must be in line with Islam's teachings.

The evidence that supports indigenous sovereignty was sourced from the Islamic teachings could be based on the following three local circumstances: 


\section{1) The Old Malayan Constitution}

The Malaccan Malay Sultanate was a federation that upheld Islam as the law of the land. Hukum Kanun Melaka's legitimacy as the Old Malayan Constitution was elaborated in-depth by Wan Ahmad Fauzi (2018). Hukum Kanun Melaka was a written constitution that legitimised the Malaccan Malay Sultanate as an Islamic empire which dominated the entire Malay Peninsula as it is today.

The practice of good governance, management efficiency, and the people's prosperity was evidenced through internal peace, international diplomatic relations, and having the world's most prosperous port in the 15th century. Although the provisions on the political system and administrative organs did not constitute the most significant part of Hukum Kanun Melaka, it should be understood that those were the local constitutional characteristics that existed at that time. Important posts such as Bendahara (Prime Minister), Penghulu Bendahari (Minister of Finance), Temenggong (Minister of Internal Affairs), Laksamana (Minister of External Defense), and Shahbandar (Minister of Customs) needed to be seen in a larger frame than the individual. There were various ministries described through the Malay customs that today are spelt out in statutes. Besides, it should be seen through the current framework as a constitution. In other words, the traditional political system underpinned with the concept of caliphate had enormously contributed to the glory of the Malaccan Malay Sultanate. During its peak period, the sultans of Malacca were well-known with their justice and shura practice (consultation). Such attributes of the Malay Rulers were the critical success of their sultanate and have become the study for the world-class good governance ethics as propounded by Wan Ahmad Fauzi (2020).

The form of the Malaccan Malay Sultanate also conformed to a modern constitution's characteristics as defined by Hood Philip and Jackson (2001). A modern constitution embodies the system of laws, customs and conventions that define the composition and powers of organs of the state and regulate the various states' relations to one another and the private citizen. Hukum Kanun Melaka, the acceptance of the Islamic law as the source of legislation and implementing a well-organised government system during the Malaccan Malay Sultanate, could rebut some orientalists British-Malaya who denied the existence of a constitution during the Malaccan Malay Sultanate. As a legal source, Islam was written in the Constitution of Malaya as late as 1424, when Hukum Kanun Melaka was promulgated.

The findings by Hooker (1970), Muhammad Yusoff Hashim (2015) and Liaw Yock Fang (2003) showed Hukum Kanun Melaka continued to be accepted by the Malay State Governments despite the dissolution of the Malaccan Malay Sultanate around the late 17th century while in Johor. The continuance of Hukum Kanun Melaka could be seen in the Laws of Johor, the Laws of Pahang, the Laws of Kedah, and Sungai Ujung's Laws. Scholars such as Harding (1996) agreed that the Malay States constitution's foundations were rooted in the Malacca Malay Sultanate. The government's legitimacy was built on the Islamic principles with the usage of terms, 'caliphs,' 'ruler, 'sultan,' the appropriation of yellow colour and the ceremonial regalia. Finally, around the late 19th and early 20th centuries, saw the emergence of a written European style constitution, i.e. the Johor State Constitution (1895) and the Laws of the Constitution of Terengganu (1911). Again the above modern styled constitutions did not abolish the Malay Rulers' position as a sultan or caliph.

\section{2) Islam as the law of the land}

The belief in the Islamic faith is fundamental because Islam is ad-Din (The religion). During the Malaccan Malay Sultanate, Islam was accepted as universal, not limited to specific worship or rituals such as praying and fasting during Ramadhan or muamalat (Islamic transaction).

Hukum Kanun Melaka (Liaw Yock Fang 2003) consisted of various types of laws: constitution, crime, land, bondage, contract, representation, family, maritime and Islamic principles. The Islamic law also contained the law of sale and purchase, court procedures, Qisas law and the Islamic Criminal law or Hudud. The existence of the Islamic laws and principles and the customary law in Hukum Kanun Melaka gave great significance. Islam recognised some of the customs that did not contradict Islamic principles as uruf al-muhakkamah (customary Islamic practice). Wan Ahmad Fauzi (2013) concluded that Islam had held the status as the law of the land during the Malaccan Malay Sultanate, for without such status, it would be impossible for Islam to be a 'unified central core element' of the Malay identity.

The evidence that Islam continued to be in authority in the Malay States could be traced in the Johor State Constitution of 1895. Clause LVII of the Johor State Constitution provided, "What is called the 'Religion of the State' for this territory is the Mohamedan Religion, and such being the case, the Mohamedan Religion shall continuously and forever be, and be acknowledged to be, and spoken of as, the 'State Religion', ..". The same provision was contained in Clause 51 of the Law of the Constitution of Terengganu 1911i. The modern written constitutions for the Johor and Terengganu were a thorough and prudent measure to deal with the British threats after witnessing the interference of the said foreign power in the Federated Malay States' affairs. In the above modern constitution, apart from Islam's declaration as the State religion, the rulers and ministers were also required to be Muslims. Although other Malay states had had only modern constitutions after 1948,ii, however, the confirmation of Islam as a State religion is stipulated in every state constitution at present.iii

From another perspective being Muslims, the Malay Ruler and the head of religion and a supreme ruler could not dismiss his obligations to obey Allah SWT's command.iv The responsibility of a ruler as the supreme leader is to implement Allah SWT's laws. Such obligation is in line with His command in Surah al-Ma'idah (5, verse 45), "And whoever does not punish by what Allah has revealed, they are the unjust." Even though the modern concept stipulates such sovereignty is possessed by the Malay Rulers, sovereignty ownership is in fact trust. As explained previously, the phrase 'Allah SWT's vicegerent on earth' was understood by the rulers in accordance with the concept inherited from generation to generation. 


\section{3) Contemporary Local Thinking}

According to Andaya (1984), when Parameswara reverted to Islam, his reign was reinforced with Islamic teachings' concepts and procedures that a ruler was Allah SWT's vicegerent on earth. This concept, at once bound a ruler to his faith in Islam. Stockwell (1977) stated, "Traditionally, the Sultan was regarded as the fount of all law and government and the head of religion; he defended the adat (custom) the very fabric of the Malay society, and was God's vicegerent in the world". Essentially the position of the ruler as Allah SWT's vicegerent on earth explained the principles of indigenous sovereignty based on the Islamic teachings. This statement was agreed by Salleh Abas, LP in Che Omar during the Malaccan Malay Sultanate period.

According to Yusuf al-Qaradhawi (2009), absolute sovereignty belonged solely to Allah SWT. The rulers, government or leaders in Islam are positioned as caliph or vicegerents of Allah SWT who continue Prophet Muhammad's (PBUH) responsibility as the state's leader. A ruler or government holds Allah's SWT absolute sovereignty in the form of sovereign trust. Surah Ali 'Imran (3, verse 26) reads:

Say ye (Oh Muhammad); Oh Allah who has the power of governing! You are the One who empowers whoever You desire to govern and You are The One who revokes the power of governing whoever You desire. You are the One who glorifies whom You desire and You are the One who despises whom You desire. Only in Your authority has all goodness. Indeed, You have the authority over all things.

Sovereignty in the form of trust explains the characteristics of Malaya's indigenous sovereignty based on the teachings of Islam. Such a position provides the prerogative of a Muslim ruler. As a Muslim, the ruler is obliged to implement the rules fairly in accordance with the Islamic injunctions. The Malaccan Malay Sultanate's position as khilafah Islamiyyah (Islamic state) became more apparent when Hukum Kanun Melaka was instituted during the reign of Sultan Muhammad Shah (1424-1444). The concept of sovereign trust not only emanated from Hukum Kanun Melaka and the position of Islam in Malacca, but it was reinforced through the commands of the Malay Rulers in their Wills to their successors. Among the Wills is of Sultan Mansor Shah to his prince, Raja Husin:

Let it be known, my son, this world is not eternal. The living will soon die too. Complete faith and good character, are eternal and remembered forever. In my absence, my son, be patient and fair, and do not greed for other's property, for taking your Muslim brethren's possession is a great sin, unless, with their permission, there will be no clemency from Allah SWT. And do not avoid to be among people, they are all Allah SWT's servants, and they are your responsibility. If they are in difficulties, help them; if they are persecuted, you must judge them carefully, so that in the Hereafter, Allah will not punish you, as the Prophet (PBUH) stated; kullukum rain wa kullukum masuulun ala raiyatihi, i.e. all of you will be questioned on your deeds; which means in the Hereafter, Allah SWT will question the people on their rulers' judgement. Therefore, it is necessary to be just and fair, so that later in the Hereafter, Allah SWT will lighten your sins (bad deeds). And let there be a consensus among all the ministers and all other nobilities, for the ruler, even with his knowledge and wisdom cannot practise his wisdom without consensus among all his officials. And there will be no peace in his reign, because the ruler is like fire, and the ministers are like wood; if there is no wood, where can there be a burning fire? As Farsi says, "Arayat juna bhasanat sultan khasad",i.e. the people are like roots, whose ruler is the tree; if there are no roots, no tree can stand by itself, so is the ruler and his people. Oh my son, do honour my will, so you will receive Allah's SWT blessings (W.G. Shellabear: 1991, translated by the author).

It is essential to mention here that according to Imam Shafei r.a, any state that had ever been an Islamic state, its status remains in accordance with the law of Feqah. This means that an Islamic state, even if conquered by the communist government or any other foreign powers, will not lose its status as an Islamic State, but instead, it is the Muslims' responsibility to free themselves when able. It was found that the above thought was understood not only by the Malay Rulers as witnessed in the above will, and even in the contemporary local writings by scholars of that time such as Raja Ali Haji and many others. Gurindam Duabelas was one of the beautiful examples.

\section{THE ANALYSIS OF CHE OMAR'S CASE}

To assess whether the Court adopted the correct interpretation of Islam in the case of Che Omar, it is necessary to examine the ground of Judgment in a bit of detail. The essence of the observations by Salleh Abas LP in the case was as follows;

1. Prior to the British's arrival, the position of the Malay rulers as 'Allah SWT's vicegerent' was confirmed, in the said concept, the ruler has entrusted the power to implement the rule based on the laws as revealed by Allah SWT and subsequently enforced them.

2. Starting with the Pangkor Treaty 1874 and other subsequent treaties, the introduction of the doctrine of advice resulted in Islam's teachings were separated to be public and private aspects.

3. The British had transferred the sovereignty to the ruler, and consequently, the concept of 'Allah SWT's vicegerent' on earth was erased. The ruler then was considered a sovereign within his territory. 
Upon reading the entire Judgment of his lordship, it was found the contents of the above treaty any other treaties involving the sultanate of Perak were not examined, in fact, his lordship had relied solely on the opinions in MB Hooker's book, Islamic Law in South-east Asia, 1984. What was more saddening, no argument touched the implication of the principles of the Malay Rulers' sovereignty towards the British's policies. Instead, the said principles were deemed lost due to the introduction of the doctrine of advice as early as the Pangkor Treaty 1874. The advice doctrine meant the ruler had to consult the British resident or adviser and act according to such advice. Nevertheless, there was an exception in the advice doctrine, especially on matters of the Islamic religion and Malay customs.

One of Che Omar's Judgment's more important matters is the interpretation of Islam and its implication by Salleh Abas LP. This article holds that if his lordship properly examined the objectives of the Pangkor Treaty 1874 and took into account the written constitution of Perak at the material time, it was favourable for the Court to interpret Islam in Article 3, based on the definition given by S Abul A'ala Maududi. The definition of Islam by S Abul A'ala Maududi was derived from the al-Quran and al-Sunnah.

This article firmly holds that the doctrine of advice did not challenge indigenous sovereignty principles sourced from Islamic teachings. It was the doctrine to be construed as subject to the principles of Syariah compliance in reliance upon the written constitution of Perak at the material time, i.e. Hukum Kanun Perak and Undang-Undang 99 Perak that retained Islam as the law of the land. The above principle was in line with the three local circumstances already elaborated above; First, Hukum Kanun Melaka as the Old Malayan Constitution. Second, Islam as the law of the land and third the contemporary local thinking on the principle of sovereignty itself.

In Che Omar's case, Salleh Abas LP himself admitted the effect of the defence counsel's argumentation would have a significant implication on laws if Islam was given an accurate interpretation as it is understood, his lordship said:

On the other hand, if the religion of Islam or Islam itself is an all-embracing concept, as is generally understood, which not only the ritualistic aspect but also a comprehensive system of life, including its jurisprudence and moral standard, then the submission has a great implication in that every law has to be tested according to this yardstick.

As argued by Salleh Abas LP, article 162 of the Federal Constitution does not preclude the implementation of Islamic jurisprudence as had been exalted in Malaya. Such provision permitted the implementation of the existing laws until it would be repealed by the authority having the power to do so and in fact, it could continue to be in effect with whatever modifications made therein under Article 162. Any order to bring the existing laws into accord with the provisions of the Federal Constitution should not be viewed as an action to maintain secular laws distinguished from the civil laws as permitted pursuant to Civil Law Act 1956 (Revised 1972). Even Salleh Abas (1984) admitted:

When the Portuguese and the Dutch left and were subsequently succeeded by the British, the Islamic religion was left undisturbed. Although the British through a series of treaties of peace and friendship with Malay Rulers secured rights to make their advice prevail upon the Rulers in all matters pertaining to the government of the country, they, however, excluded the religion of Islam from the spree of their advice.

\section{IMPLICATIONS OF THE PANGKOR TREATY 1874 AND THE DOCTRINE OF ADVICE}

In Che Omar's case, the concept of rulers as caliphs was faded away as a result in the introduction of the Pangkor Treaty 1874. The validity of the Court's observations, in this case, must be reviewed according to the indigenous rather than the Western framework. The Western framework was an evaluation based on Western laws' principles, or more specifically, how the Western thought interpreted sovereignty.

The Pangkor Treaty 1874 was made between the Governor of the Straits Settlements Sir Andrew Clarke with the Raja Muda Abdullah and some nobilities of the Perak Malay State at the latter's request. The issue often raised that the doctrine of advice was a principle that required a ruler to act according to the executive's advice is a form of colonisation. The doctrine was contained in Clause 6 of the Pangkor Treaty 1874, which stated the Sultan of Perak should accept a British resident whose advice should be sought, and that the sultan must act in accordance with the advice of all matters except those affecting the religion of Islam and customs.

Whether or not the doctrine of advice as contained in the Pangkor Treaty 1874 altered the sovereignty of the Sultan of Perak should be assessed from the conceptual points of views. According to Wan Ahmad Fauzi (2017), the concept of sovereignty comprised the source and characteristics of sovereignty. The source of sovereignty and sovereignty characteristics are two main aspects that determine the prevailing principle of local sovereignty. The two aspects shape the legal principles and political systems of a government. The legal and political systems are considered voidable if they conflicted with the characteristics of a state's sovereignty. The two aspects in the concept of sovereignty are the parameter or assessment of whether a state's independence had been seized or preserved.

The reasons and objectives of the Pangkor Treaty 1874 should be due examined in order to answer whether the Perak Malay State was colonised thus the Pangkor Treaty 1874 had changed the status of the Perak Sultan as Allah SWT's vicegerent on earth to his personal domain. The reasons and objectives of the Pangkor Treaty 1874 which led to the terms of the agreement are clearly stated as follows:

1. The chaotic situations had resulted in the need to; First, a robust political system in the Perak Malay State. Second, an effective authority to warrant people's protection and successful industrial production.

2. The large Chinese population and investments by the British citizens as well as other residents of the British territories involved tin mining enterprises; the situation of the mines and the not fully protected properties, the 
occurrence of piracy, murder cases and massive burning crimes in the country which resulted in losses to British trades and interests, as well as threats to the security of the Straits Settlements.

3. A partial acknowledgment of the nobilities who could not address current problems and requests from stakeholders in domestic enterprises.

4. The British government's commitment as sealed in the Treaty to protect the Perak Malay State and assist the rulers.

The above statements are imperative and should not be neglected when proposing the effects of Clause 6 to the sovereignty of the Sultan of Perak. Looking into the Malay tradition, the rules upon advice or the 'rulers in council' were not a new governance principle. Even Islam itself demands the practice of shura (consultation) in managing a government. The extent to which Clause 6 of the Pangkor Treaty 1874 threatened the principles of the indigenous sovereignty, lay in the answer contained in Clause 6 itself; in fact from the legal point of view, the Pangkor Treaty 1874 should be read together with Hukum Kanun Melaka, Hukum Kanun Perak and Undang-Undang 99 Perak, which were the written constitutions of the Malay State of Perak. Although the two constitutions were not modern, as they are known today, it could not be denied that either one of the Constitutions was the supreme law at the material time in Perak.

The extent of the advisers' authority was also an element that needed to be examined. The Pangkor Treaty 1874 did not give the British residents absolute authority to impeach to the point of altering the sovereignty of the Sultan of Perak. This is because the introduction of Clause 6 in the Pangkor Treaty 1874 was intended to manage the stated reasons and objectives, and it preceded all other terms of the agreement therein. On the other hand, an imposed advice for the sake of safety and mutual benefits, should not be regarded as colonisation even though there were elements of 'indirect rule'. This is because the British intervention in Perak was subjected to the Pangkor Treaty 1874, and the Pangkor Treaty 1874 itself was subjected to the Constitution of Perak. In short, although the Sultan of Perak was required to act upon the Resident's advice, however, the principal obligation of the Resident was to provide advice, and not to rule.vi

It could not be denied that the Pangkor Treaty 1874 led to the introduction of 'English common law '. The adoption of the common law principle in Malaya officially began in the Straits Settlements by introducing the Charter of Justice dated 25 March 1807. The new administration of justice was introduced to manage the ruler's subjects and the British subjects and the immigrants. Here it is emphasised that the law of England was never enforced in the state of Perak. The legal authority remains in the Sultan of Perak who acted based upon consultation. Sproule Ag affirmed this principle. CJ in the case of Re the will of Yap Kim Seng as follows;

It is submitted to me, therefore that one prime cause for the adoption of the rule in the Colony is absent here, seeing that these States never were either ceded or newly settled territory, but States which by treaty invited a certain measure of British protection and control. The general law of England was never introduced or adopted here at any time. The most that can be said was that portions of that law were introduced by legislation which adopted, not English law, but English principle and models for local laws.

The legitimacy of the English common law that dominated the local legislation from time to time in Perak should be answered to the extent it did not contradict the principle of the sovereignty of his ruler inherited from the Malaccan Malay Sultanate. Although the courts conducted by the British judges seemed to sideline the Islamic laws and jurisprudence continuously, it, however, did not mean that the English common law and the rules of equity had lawfully replaced the former as the law of the land. As a matter of fact, Islam was recognised as the law of the land in the case of Ramah vs Laton.

The development of the English common laws and the rules of equity was due to the British judges' ignorance on the Islamic laws and jurisprudence. It did not alter the position of Islam as the characteristic of the principle of the existing sovereignty. That statement is in line with the case of Emporium Motor Emporium vs Arumugam when Terrell Ag. CJ stated:

It is said that the English rules of equity, as administered by the Court of Chancery, have no application in the Federated Malay States, as the Court has not been given the jurisdiction of the Court of Chancery, nor is there any Civil Enactment incorporating into the law of the Federated Malay States the equitable principles applied in England. This is perfectly true so far as it goes, but under section 49(1) of the Courts Enactment, the Supreme Court has the widest possible jurisdiction in all suits, matters and questions of a civil nature, and although the legislature has given no indication on what principles such jurisdiction should be exercised, every Court must have inherent jurisdiction to do justice between the parties, and apply such principles as are necessary or desirable for attaining such object, and for giving decisions which are in conformity with the requirements of the social conditions of the community where the law is administered..... The Courts of the Federated Malay States have on many occasions, acted on equitable principles, not because English rules of equity apply, but because such rules happen to conform to the principles of natural justice.

It is necessary to note that statutes introducing the administration of civil laws in the Federated Malay States were only formed and enforced through Civil Law Enactment No. 3, 1937. The enactment permitted the usage of the English common law and the rules of equity as was administered in England subjected to requirements, "so far only as the circumstances of the Federated Malay States and its habitants permit and subject to such qualifications as local circumstances render necessary". In fact the provision did not permit the import of the English common law and the rules 
of equity arbitrarily, it could only be adopted in the Federated Malay States with modification to suit with local situations and subject to local circumstances. Professor Ahmad Ibrahim (2015) was of the opinion the Civil Law Enactment No. 3, 1937 only confirmed in the form of statutes to the Court practices before it, it did not at will allow the use of the English common law and rules of equity without taking into considerations the requirements set forth.

Furthermore, the establishment of various institutions by the Perak Malay State government upon British residents' advice should be considered from the aspect of the British Government's commitment to assist the Perak Malay State government as embodied in the Pangkor Treaty 1874. The ordinances and enactments were still promulgated in the name and authority of the Sultan of Perak. The modernisation of various institutions such as government departments, policing, justice systems, land administration, and public management showed that the British intervention did not serve the onesided interest. Upon examining all the agreements or treaties compiled in Allen, J. de, AJ Stockwell and LR Wright (eds.) 1981, it was found that underlying principle made between the Malay Rulers and the British representatives, the advice of the British officers was only on matters other than those pertaining to Islam and Malay customs.

Stockwell's (1979) statement, "Traditionally, therefore, the Malay Sultan was regarded as the fount of all law and government and the head of religion; he defended the adat (custom) and the structure of Malay society. Others might exercise his power, carry out his duties or guide him with his policies but the justification for all authoritative actions lay in the sovereignty of the Malay rulers" explained wholly what happened during the British intervention period in Malaya.

Verily the definition of Islam as adopted in Lina Joy's case is reflective of what had been understood before Independence Day. It should be understood in a bigger perspective and as a matter of fact, underpin the principle of laws both in the Federal and States jurisdiction as enshrined in the $9^{\text {th }}$ Schedule of the Federal Constitution. Similarly Tan Sri Hashim Yeop Abdullah Sani (1980) stressed, "Since Article 3 of the Constitution is very clear and cannot be remanipulated that the Country's religion is Islam and as such, any interpretations which create contradictions between the human-created documents (Constitution) and Allah SWT's command (al-Qur'an and al-Sunnah) cannot be adopted". The statement was supported by the former Chief Justice Tun Ahmad Fairuz bin Dato' Sheikh Abdul Halim in his talk entitled "Islam as the law of the land " on 15 March 2017 at Majestic Hotel, Kuala Lumpur.

\section{CONCLUSION}

The above facts and analyses prove that the Malay Rulers' position in the British's pre and post-intervention in their states' affairs being a caliph remains. The doctrine of advice did not alter Their position as a caliph. As stipulated in the various treaties, the doctrine of advice did not abrogate the Old Malayan Constitution's supremacy, the respective state constitution and Islamic faith as embraced by the Malay Rulers. As such, Islam as a legal doctrine in Malaya in preIndependence Day could not be construed in such a dichotomous perspective. In its true meaning as defined in al-Qur'an and al-Sunnah, Islam is the only valid interpretation in the framework of the indigenous Malaya.

Therefore, Islam is not just about a mere collection of dogmas and rituals, but it is a complete way of life covering all human activities, they may be private or public, legal, political, economic, social, cultural, moral or judicial. This way of ordering the life with all the precepts and moral standards is based on divine guidance through His prophets, and the last of such guidance is the Quran, and the last messenger is Mohammad SAW whose conduct and utterance are revered. The above is the correct interpretation of Islam and should define Islam as stipulated in Article 3 of the Federal Constitution.

\section{REFERENCES}

Ahmad Ibrahim. Common law in Malaysia (1989) 1(1) KANUN 3-25

Allen, J. de, A. J. Stockwell and L. R. Wright (eds.) 1981. A Collection of Treaties and Other Documents Affecting the States of Malaysia. Vol. 2 London: Oceana Publications.

Andaya, Barbara W. \& Leonard Y. Andaya. 1984. A History of Malaysia. Hong Kong: Macmillan Press.

Arieff Salleh Rosman \& Yahaya Jusoh. 2015. Tafsir Maudhu'iy; Politik dan Urus Tadbir. Kuala Lumpur: Dewan Bahasa dan Pustaka. Curzon, L.B. 2007. Dictionary of Law. Ed. ke-6. Kuala Lumpur: International Law Book Services.

Harding, Andrew. 1996. Law, Government and the Constitution in Malaysia. Kuala Lumpur: Malayan Law Journal Sdn. Bhd.

Hashim Yeop A. Sani, Datuk 1980. Perlembagaan Kita. Kuala Lumpur: Malaysian Law Publisher.

Liaw Yock Fang (Ketua Editor Hassan Ahmad). 2003. Karya Agung: Undang-Undang Melaka. Kuala Lumpur: Yayasan Karyawan.

Lina Joy vs The Federal Territory Islamic Religious Council \& et.al. JH (1428), Vol. 24 Sect. 1)

Lopez, Carolina. 2001. The British Presence in the Malay World: A Meeting of Civilisational Traditions. Sari 19 (2001): 3-33.

MB Hooker, Islamic Law in South-east Asia, 1984.

Meor Atiqurrahman Ishak \& Ors vs Fatimah Sihi \& et.al. [2006] 4MLJ 605

Mohamed Anwar Omardin, Wan Ahmad Fauzi Wan Husain, Mat Zin Mat Kib \& Junaidi Abu Bakar. Peranan UMNO Menegakkan Islam Dalam Perlembagaan Persekutuan: Satu Kajian Secara Kronologikal. Akademika Vol 87, No 1 (2017).

Mohammed al-Baianonie, Imam. In his Friday speech at Islamic Centre of Raleigh, North California on December, $27,1996$. www.Islam1.org/khutub/defn

Mohd Salleh Abas, Tan Sri Dato' Haji. 1984. Selected Article \& Speeches on Constitution, Law \& Judiciary. Kuala Lumpur: Malaysia Law Publisher Sdn. Bhd. 
Muhammad Yusof Hashim. 1992. The Malay Sultanate of Malacca. Kuala Lumpur: Dewan Bahasa dan Pustaka.

Philpott, D. Sovereignty. Stanford Encyclopedia of Philosophy. https://plato.stanford. edu/entries/sovereignty.

Ramah vs Laton [1927] 6FMSLR 128

Re Yap Kwan Seng's Will [1924] 4FMSLR 313

Ridzuan Awang. 1994. Undang-Undang Tanah Islam; Pendekatan Perbandingan. Selangor: Percetakan Dewan Bahasa dan Pustaka.

S Abul A'ala Maududi, The Islamic Law and Consttution, March 1980, (7th. Edition).

Stockwell, A. J. 1979. British Policy and Malay Politics during the Malayan Union Experiment, 1942-1948. Kuala Lumpur: Malaysian Branch of the Royal Asiatic Society.

W.G. Shellaber. 1977 (Edisi Ketiga). Sejarah Melayu. Selangor: Penerbit Fajar Bakti Sdn. Bhd.

Wan Ahmad Fauzi bin Wan Husain, YB Datuk. 2013. Rekonfigurasi Epistimologi Jati Diri Melayu: Manifestasinya Ke Atas Silat Seni Gayong. Latihan Ilmiah Sarjana Falsafah Jabatan Sains Sosial Dan Kemasyarakatan sesi 2012/13. Universiti Kebangsaan Malaysia.

Wan Ahmad Fauzi Wan Husain. 2017. Konsep Kedaulatan Watan Raja-Raja Melayu Dalam Perlembagaan Persekutuan Malaysia Menurut Sejarah Perundangan. Tesis Ph.D, Universiti Kebangsaan Malaysia, Bangi.

Wan Ahmad Fauzi Wan Husain. 2018. Kedaulatan Raja-Raja Melayu: Jurisprudens, Governan \& Prinsip Perlembagaan Persekutuan. Selangor: Abad Sinergi Sdn. Bhd.

Wan Ahmad Fauzi Wan Husain. 2020. The Conceptual Framework for Building The World Class Good Governance Ethics. Journal of Governance and Integrity, UMP. Vol. 4 Issue 2, December 2020.

Yusuf al-Qardhawi. 2009. Fiqh Kenegaraan. Kuala Lumpur: Blue-T Publication Sdn. Bhd.

\section{NOTES}

i. Indeed it was described and mentioned and indefinitely established that this Terengganu Government was the Islamiyyah Melayuwiyyah Government which was said to be the religion of the State and the Government, so no other religion could at all be made or called the religion of the State even though there were other races and religions allowed to remain peacefully in the State and territory of Terengganu.

ii. The Malay States of Pahang, Perak, Kedah and Kelantan adopted the written laws developed from the Malacca Code in line with the reinforcement of Islamic laws until introducing the British laws in the court when the British advisory system was enforced.

iii. For example, Clause 5 of the State Constitution of Negeri Sembilan (Part One) 1959 provided; "This State Religion is Islam as embraced and practised in this state: but other religions can be practised peacefully anywhere in the country by those who embraced them."

iv. As enshrined in each of the State Constitution, as a requirement (1) Clause 4 of the Terengganu State Government Laws(Part One):

The Religious Leader of this State is His Royal Highness and The Council of Islamic Religion and Malay Customs, which in the English language is called the "Council of Religion and Malay Customs" instituted under the existing State Laws and shall continue to assist and advise His Royal Highness according to those laws.

\section{v. Salleh Abas LP stated:}

Before the British came to Malaya, which was then known as Malaya, the sultans in each of their respective states were the heads not only of the religion of Islam but also the political leaders in their states, which themselves Muslims, their subjects were also Muslims, and the law applicable in the states was Muslim law. Under such, the sultan was regarded as God's vicegerent (representative) on earth. He was entrusted with the power to run the country in accordance with the law ordained by Islam, i.e. Islamic law and to see that the law was enforced.

vi. The Colonial Secretary to Residents, 17 May 1878, "The Residents have been placed in the native states as advisers, not as rulers. If they upon themselves to disregard this principle, they will most assuredly be held responsible if trouble springs out of their neglect of it." 


\section{REFERENCES}

Huang, X., Sun, J., \& Sun, J. (2018). A car-following model considering asymmetric driving behavior based on long short-term memory neural networks. Transportation Research Part C: Emerging Technologies, 95(February), 346-362. https://doi.org/10.1016/j.trc.2018.07.022

James, S. L., Abate, D., Abate, K. H., Abay, S. M., Abbafati, C., Abbasi, N., Abbastabar, H., Abd-Allah, F., Abdela, J., Abdelalim, A., Abdollahpour, I., Abdulkader, R. S., Abebe, Z., Abera, S. F., Abil, O. Z., Abraha, H. N., Abu-Raddad, L. J., Abu-Rmeileh, N. M. E., Accrombessi, M. M. K., ... Murray, C. J. L. (2018). Global, regional, and national incidence, prevalence, and years lived with disability for 354 diseases and injuries for 195 countries and territories, 1990-2017: a systematic analysis for the Global Burden of Disease Study 2017. The Lancet, 392(10159), 1789-1858. https://doi.org/10.1016/S0140-6736(18)32279-7

Tan, H., Qin, L., Jiang, Z., Wu, Y., \& Ran, B. (2018). A hybrid deep learning based traffic flow prediction method and its understanding. Transportation Research Part C: Emerging Technologies, 90(January), 166-180. https://doi.org/10.1016/j.trc.2018.03.001

Taylor, K., Post, A., Hoshizaki, T. B., \& Gilchrist, M. D. (2019). The effect of a novel impact management strategy on maximum principal strain for reconstructions of American football concussive events. Proceedings of the Institution of Mechanical Engineers, Part P: Journal of Sports Engineering and Technology, 233(4), 503-513. https://doi.org/10.1177/1754337119857434

\section{CONFLICT OF INTEREST}

The author(s), as noted, certify that they have NO affiliations with or involvement in any organisation or agency with any financial interest (such as honoraria; educational grants; participation in speakers' bureaus; membership, jobs, consultancies, stock ownership, or other equity interest; and expert testimony or patent-licensing arrangements), or nonfinancial interest (such as personal or professional relationships, affiliations, expertise or beliefs) in the subject matter or materials addressed in this manuscript.

\section{AUTHORS' BIOGRAPHY}

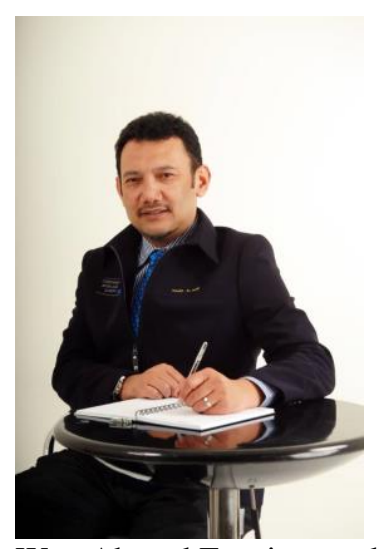

Wan Ahmad Fauzi was admitted as an advocate \& solicitor at the High Court of Malaya, Kuala Lumpur on 23 September 1996. He is also qualified as a Syar'ie counsel for the State of Terengganu and the Federal Territories. In 2012, he was listed in "The Book of Malaysia Leaders: Political, Government \& Corporate.

He once held a few prominent posts such as the Secretary of Terengganu Council of The Royal Court. At presence, he actively involves in NGOs. He obtained his PhD in constitutional law together with the certificates of Graduate on Time and Distinction PhD Thesis from the Law Faculty of The National University of Malaysia. Wan Ahmad Fauzi is the founder of Watan Jurisprudence. In recognizing his great contribution to our country, he was conferred a few Royal Awards such as PJN., DPNS., SMT. 